\title{
ポリ塩化ビニルと無機充てん剂間の 相互作用
}

（昭和60年 9 月 9 日 受理）

\section{相馬勲*1 岸 部 正 行*2}

\begin{abstract}
要 旨 PVCとマイカ, ゾノトライト及び炭酸カルシウムのそれぞれの複合系について, Pliskin あるい はZiegel の方法を用いて複合界面近傍の不動層(バウンドポリマー)の厚さ $\Delta R$ を測定した. Pliskin 法から 求めた $\Delta R$ はマイカ系が約 $230 \AA$ ， シラン処理ゾノトライトは約 $150 \AA$, 未処理ゾノトライトで約 $90 \AA \AA$ とい う值が得られた，炭酸カルシウムについては測定できないほど小さかった。一方, Ziegel 法で求めると $\Delta R$ としては不適当と思われる大きな值であった．ただし $\Delta R$ の大きさの順番は Pliskin 法の場合と同じで, 相 互作用の強弱の評価は可能である. 次に力学的性質と $\Delta R$ の大きさの関係は特に弾性率との相関性が強く認 められた.
\end{abstract}

\section{1. 諸言}

複合材料においては,マトリックスと強化材又は充て ん剂との間の相互作用は極めて重要な意味を持つ。なぜ ならば，力学的性質あるいは熱的性質を始めとして各種 物性が界面における相互作用に強く影響されるからであ る.しかし, 相互作用は界面での様ざまな状態や両者の 間に㗢く静電的な力やファンデルワールスカあるいは化 学結合の存在などによって異なり, その強さを直接知る ことは不可能である. それでは強さを評価する手だてが 全くないかというとそうではなく, バウンドポリマーの 厚さから間接的に評価することは可能である. バウンド ポリマーの厚さを測定あるいは推定する方法について は, いくつかの方法があるが, 定量的な方法としては次 の三つが代表的なものである. 第 1 はフィラーの充てん に伴うガラス転移温度の上昇度から誘導する Droste ら の方法である1). 第 2 は相互作用によってフイラー表面 上に吸着されたポリマーを可溶性ポリマーと分離して定 量するPliskin らの方法である ${ }^{2)}$. 第 3 は動的粘弾性に おけるエネルギー分散を測定して求めるZiegel の方法 である゙).

著者は以前に PVC-ゾノトライト系について Droste らの方法により不動層の厚さを測定したことがある. そ の結果, PVCとゾノトライトの間には相当強い相互作

*1 大阪工業技術試験所第 2 部( $\mathbf{T} 563$ 池田市緑ケ丘 1-8-31)

*2 兵庫県皮革工業指導所 ( $\mathbf{T} 670$ 姫路市野里字東河 原)
用が働らいていることが推定された4). 今回, Pliskin 法 とZiegel 法によって測定した結果, 以前の Droste 法と 今回の Pliskin 法とがよく一致した. 更に今回, ゾノト ライトに加えてマイカと炭酸カルシウムについても測定 を行ない, かつ力学的性質との関連性も併せて調べたの で報告する.

\section{2. 理 論}

\subsection{Pliskin 法}

Pliskin らはカーボンブラックに吸着されたバウンド ラバーの厚みを求める手段として，トルエンなど溶剂で 可溶性部分を溶解除去し, 残った不溶性部分の量から厚 みを求める方法を提出した。、いま，見掛けのバウンドラ バーの分率を $[B R]$, カーボンブラックによって不溶化 したゴムの分率を $[A R]$, ゴム自身のゲル分率を $G$ とす ると,

$$
[B R]=[A R]+G
$$

また不溶部分のゴムの体積 $V_{A R}$ は

$$
V_{A R}=\Delta R S^{\prime}
$$

ここで, $\Delta R$ はバウンドラバーの厚み, $S^{\prime}$ はゴムと接触 しているカーボンブラックの表面積である. したがって ゴムの体積を $V_{G}$ とすると

$$
[A R]=\frac{V_{A R}}{V_{G}}=\frac{\Delta R S^{\prime}}{V_{G}}
$$

いま, $f=S^{\prime} / S(S:$ カーボンブラックの全表面積), カー ボンブラックの体積を $V_{C B}$ とすると

$$
[A R]=\Delta R f\left(\frac{S}{V_{G}}\right)
$$




$$
\begin{aligned}
& \left(\frac{S}{V_{G}}\right)=\left(\frac{V_{C B}}{V_{G}}\right)\left(\frac{S}{V}\right)_{C B} \\
& \left(\frac{V_{C B}}{V}\right)=\frac{\phi}{1-\phi}
\end{aligned}
$$

となる. $\phi$ はカーボンブラックの体積分率である. また カーボンブラックの密度を $\rho$, 比表面積を $A$ とすると

$$
\left(\frac{S}{V}\right)_{C B}=\rho A
$$

したがって

$$
\begin{aligned}
& {[A R]=\Delta R f\left(\frac{\phi \rho A}{1-\phi}\right)} \\
& {[B R]=\Delta R f\left(\frac{\phi \rho A}{1-\phi}\right)+G}
\end{aligned}
$$

となる。そこでソックスレーなどを使用して求めた $[B R]$ と $\phi \rho A / 1$ - $\phi$ 関係をプロットすると直線になる はずで，その勾配が $\Delta R f ，$ 切片が $G$ となる．ここで問 題は $S^{\prime}$ の值を知ることが現実には不可能なことである. $S^{\prime}$ はマトリックス中のフィラーの相互作用に寄与する 有効表面積, したがって $f$ は寄与率(有効係数) と見なす ことができる. 本研究での $S^{\prime}$ の推定方法については本 論で述べる.

\subsection{Ziegel 法}

バウンドポリマーの厚さ，すなわち相互作用によって フィラー表面で拘束されているマトリックスポリマーの 平均距離 $\Delta R$ を求める方法として Ziegel は不動層をフ ィラーと一体と考え, フィラーの厚みが $\Delta R$ だけ増加し たとして以下の理論を展開した. すなわち，バイブロン などで振動を加えたときのエネルギー発散(消費)がマト リックスの体積 $\left(\phi_{M}\right)$ より $\Delta R$ 分の体積だけ減少すると して次の式が成立する.

$$
\begin{aligned}
& W_{0}=\pi E_{0}^{\prime \prime} \varepsilon_{0}^{2} \\
& W_{c}=\pi E_{c}^{\prime \prime} \varepsilon_{c}^{2}\left(1-\phi_{c}\right)
\end{aligned}
$$

ここで $W$ は 1 サイクルあたりのエネルギー発散量, $E^{\prime \prime}$ は損失弾性率， $\varepsilon$ はひずみである， $W_{0}$ は未充てん， $W_{c}$ は充てん采である。 $\phi_{e}$ はフィラーの有効体積分率(フィ ラーの半径 $R$ に $\Delta R$ を加味したもの)である. 上の式か ら複合体のエネルギー発散比 $W_{c} / W_{0}$ を求めると $\left(E_{0}^{\prime \prime} \fallingdotseq E_{c}^{\prime \prime}\right.$ と考えてよい),

$$
W_{c} / W_{0}=\left(\varepsilon_{c} / \varepsilon_{0}\right)^{2}\left(1-\phi_{e}\right)
$$

また, $\varepsilon_{c} / \varepsilon_{0}=1 / 1-\phi_{e}$ でこれから式(12)は

$$
W_{c} / W_{0}=1 /\left(1-\phi_{e}\right)
$$

更に, $\phi_{e}=\phi(1+\Delta R / R)^{3}, W_{c} / W_{0}=E_{c}^{\prime \prime} / E_{0}^{\prime \prime}$ として, ここ で $(1+\Delta R / R)^{3}$ を $B$ とおくと結局式(13)は

$$
W_{c} / W_{0}=E_{c}^{\prime \prime} / E_{0}^{\prime \prime}=1 /(1-\phi B)
$$

となる。なお， $\phi$ はフィラーの体積充てん率である。一 方，式(14)と Kerner の式5)(省略)を組合わせると

$$
\frac{E_{c}^{\prime}}{E_{0}^{\prime}}=\frac{1+1.5 \phi B}{1-\phi B}
$$

更に, $E^{\prime \prime} / E^{\prime}=\tan \delta$ の関係を用いれば

$$
\frac{\tan \delta_{c}}{\tan \delta_{0}}=\frac{1}{1+1.5 \phi B}
$$

となる。ここで B は相互作用パラメータと呼ばれ， $B$ の值から $\Delta R$ を知ることができる. なお, Ziegel はフィ ラーの形状別にそれぞれ次の式を提出している.

$$
\begin{aligned}
\text { 球状 } E_{c}^{\prime \prime} / E_{0}^{\prime \prime}= & {\left[1-\phi(1+\Delta R / R)^{3}\right]^{-1} } \\
\text { 棒状 } E_{c}^{\prime \prime} / E_{0}^{\prime \prime}= & {\left[1-\phi(1+\Delta R / R)^{2}\right.} \\
& \times(1+2 \Delta R / L)]^{-1}
\end{aligned}
$$

板状 $E_{c}^{\prime \prime} / E_{0}^{\prime \prime}=\left[1-\phi(1+2 \Delta R / D)^{2}\right.$

$$
\times(1+2 \Delta R / X)]^{-1}
$$

ここで, $R$ はフィラーの半径, $L$ は棒状フィラーの長さ, $D$ と $X$ は板状フィラーの直径と厚さである.

以上，粘弾性の測定から得られる $E^{\prime}, E^{\prime \prime}$ あるいは $\tan \delta$ からそれぞれ $B$ が求まり，これから $\Delta R$ を算出す ることができる.

\section{3. 実}

験

\section{1 試料の作製}

使用されたフィラーを Table 1 に示す.フィラーの充 てん量は重量比で10から $50 \%$ をで $10 \%$ おきである。それ ぞれは $165^{\circ} \mathrm{Cに}$ 加熱されたロールで 5 分間混練された. なお，ゾノトライトについてはシランカップリング剂 （信越化学 KBM 602）で処理（処理量 1 重量\%)したもの も試料に加えた。本研究では未処理及びシラン処理ゾ， トライト充てん系の記号を PX 及び PX $(\mathrm{SC})$ とした. ま たマイカ及び炭酸カルシウム充てん系を PM 及び PC と した.ここでゾノトライトとは針状のけい酸カルシウム $\left(6 \mathrm{CaO} \cdot 6 \mathrm{SiO}_{2} \cdot \mathrm{H}_{2} \mathrm{O}\right)$ である.

Table 1 Used fillers

\begin{tabular}{llccc}
\hline \multicolumn{1}{c}{ filler } & \multicolumn{1}{c}{ grade } & $\begin{array}{c}\text { size } \\
(\mu \mathrm{m})\end{array}$ & $\begin{array}{c}\mathrm{BET} \\
\left(\mathrm{m}^{2} / \mathrm{g}\right)\end{array}$ & density \\
\hline xonotlite & $\begin{array}{l}\text { KAWAI } \\
\text { PCM-LITE }\end{array}$ & $10-20$ & 15.4 & 2.7 \\
mica & $\begin{array}{l}\text { CANADAMICA } \\
\text { S-325 }\end{array}$ & $40-60$ & 0.9 & 2.8 \\
$\begin{array}{l}\text { calcium } \\
\text { carbonate }\end{array}$ & $\begin{array}{l}\text { SHIRAISHI } \\
\text { WHITON SSB }\end{array}$ & $1-3$ & 3.3 & 2.7 \\
\hline
\end{tabular}

(used PVG: NIHON-ZEON 103EP) 
Table 2 Fraction of bound polymer $[\mathrm{BR}]$ and $\phi \rho \mathrm{A} /(1-\phi)$ for each PVC-filler system

\begin{tabular}{lcllllc}
\hline & PVC/filler & $90 / 10$ & $80 / 20$ & $70 / 30$ & $60 / 40$ & $50 / 50$ \\
\hline \multirow{2}{*}{$\mathrm{PX}$} & $\begin{array}{c}{[\mathrm{BR}]} \\
\phi \rho \mathrm{A} /\end{array}$ & 0.010 & 0.023 & 0.047 & 0.070 & 0.129 \\
& $(1-\phi)$ & 2.36 & 5.37 & 9.19 & 14.21 & 21.38 \\
\hline \multirow{2}{*}{$\mathrm{PX}(\mathrm{SC})$} & $\begin{array}{c}{[\mathrm{BR}]} \\
\phi \rho \mathrm{A} /\end{array}$ & 0.010 & 0.027 & 0.062 & 0.122 & 0.229 \\
& $(1-\phi)$ & 2.39 & 5.37 & 9.21 & 14.33 & 21.49 \\
\hline \multirow{2}{*}{$\mathrm{PM}$} & $\begin{array}{c}{[\mathrm{BR}]} \\
\phi \rho \mathrm{A} /\end{array}$ & 0.006 & 0.008 & 0.011 & 0.015 & 0.027 \\
& $(1-\phi)$ & 0.134 & 0.301 & 0.516 & 0.803 & 1.204 \\
\hline
\end{tabular}

\section{2 吸着 PVC の定量}

混練されたシート状の試料約 $10 \mathrm{~g}$ を小さく切断し，科 量びんの中に入れ， $\mathrm{THF}$ を注いで蓋をし， $60^{\circ} \mathrm{C} て ゙ 15$ 時 間以上静置した. その後, 遠心分離器で溶解した PVC を除去し，沈殿したフィラーを洗浄して乾燥した。この 操作を 2 回繰り返し，可溶性の PVCを分離した．次に 得られたフィラーを石英ボートに入れ，石英燃焼管にセ ットし電気炉を用いて酸素ガス気流中 $650^{\circ} \mathrm{C}$ で30分間加 熱した. そのときの加熱減量をもってフィラーに吸着さ れた PVG 量とした。

\section{3 動的粘弾性の測定}

測定器機は, 東洋ボールドウイン DDV-2A 型レオバ イブロンを使用した。試料サイズは長さ $4 \mathrm{~cm}$ ，幅 $0.11 \sim 0.12 \mathrm{~cm}$, 厚さ約 $0.015 \mathrm{~cm}$ である. 振動周波数は $110 \mathrm{~Hz}$ ，振動ひずみは $16 \mu \mathrm{m}$ である.

\section{4 力学的性亚の測定}

各試料をダンベル型に切削成形し，インストロン引張 試験機を用いて引張強さを測定した，弾性率は応力-伸 び曲線の公配から求めた。 なお, 引張速度は $1 \mathrm{~cm} / \mathrm{min}$ である。

\section{4. 結果と考察}

\subsection{Pliskin 法からの結果}

それぞれの試料について，フィラーの表面に吸着した PVCの量から見掛けのバウンドポリマーの分率 $[B R]$ を求めたが, 結果を $\phi \rho A /(1-\phi)$ の計算值と一諸に一括 して Table 2 に示した. 炭酸カルシウムについては PVC の吸着量が極端に少なくて $[B R]$ が測定できなか った(炭酸カルシウムを $650^{\circ} \mathrm{C} て ゙$ 加熱すると脱炭酸によ る減量があるが, それを差引いた残りの減量はほとんど ない). したがってPVC と炭酸カルシウムの間の相互 作用はこの方法から評価するかぎりでは無視しうるほど

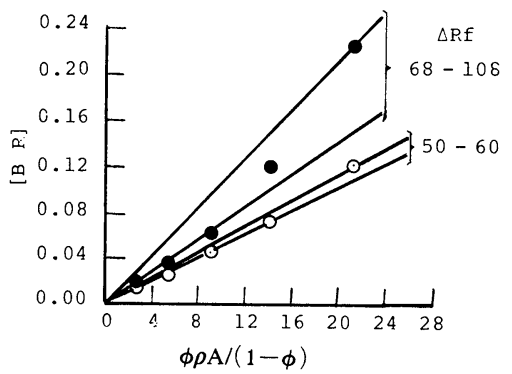

Fig. 1 Relationship between [BR] and $\phi \rho \mathrm{A} /(1-\phi)$ for xonotlite filled PVC system. $\bigcirc \mathrm{PX} \bigcirc \mathrm{PX}(\mathrm{SC})$

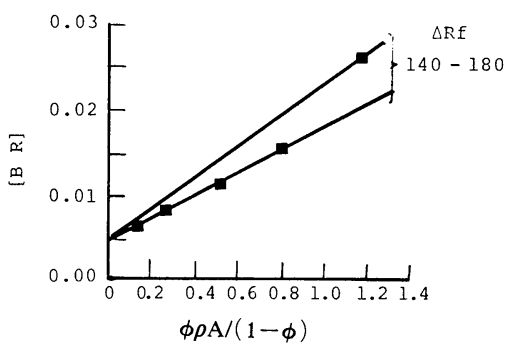

Fig. 2 Relationship between [BR] and $\phi \rho \mathrm{A} /(1-\phi)$ for mica filled PVC system. PM

小さいといえる.

Table 2 で得られた $[B R]$ と $\phi \rho A /(1-\phi)$ 関係をプ ロットすると Fig. 1 及びFig. 2 のようになる.これを 見ると充てん量の低いところでは比較的直線にのってい るが，充てん量が高くなるにつれ直線からはずれて高く なる傾向が見られる．ここでは一応図のような直線を引 き，その勾配から $\Delta R f$ を算出した. Table 3 にはその平 均值を示しておいた。 ここで問題は $\Delta R$ を求めるのに $f$ をどのように推定するかであるが，本研究では一応次の ようにして算出した. $f$ の值はガラス球のようなもので 
Table 3 The values of $\Delta R f, f$ and $\Delta R$ for each system

\begin{tabular}{lccc}
\hline system & $\Delta R f$ & $f$ & $\Delta R(\AA)$ \\
\hline PX & 55 & 0.6 & 92 \\
PX (SC) & 88 & 0.6 & 147 \\
PM & 160 & 0.7 & 230 \\
\hline
\end{tabular}

あれば 1 に近いと考えられるが，表面形状が複雑で㠜集 しやすい粒子では 1 よりかなり小さい值と予想される. そこで著者らは赤外用の $\mathrm{KBr}$ 錠剂器を利用して加圧成 形 $\left(100 \mathrm{~kg} / \mathrm{cm}^{2}\right) し$, その見掛密度と真比重の比をもって $f$ の值とした. すなわち

\section{$f=$ フィラーの見掛密度/真比重}

このような方法が果して妥当かどうか議論の余地がある が，得られた值は Table 3 に示すような結果である。こ れから得られた $\Delta R$ の值を同じく Table 3 に示した. な お, PVCの場合はゴムとちがって $G$ (ゲル分率)は無視 できる.

\subsection{Ziegel 法からの結果}

ポリマーとフィラーが接触する界面において強い相互 作用が存在すると, 界面近傍にポリマーの自由運動が拘 束された不動層が生成する。これによって弾性率が増大 し，ロスファクターである $\tan \delta$ が減少する．したがっ て動的粘弾性挙動を調べると相互作用が強いか弱いか大 略推定することは可能である，Ziegel の方法は，この動 的粘弾性から不動層の厚みを知るものであるが，概して バウンドポリマーとして常識的に考えられる厚さよりも かなり大きな值となるようである．例えばZiegel はウ レタンーガラスビーズ系の $\Delta R$ の值として $2.5 \mu \mathrm{m}$ と報告 している3).

本研究では $\mathrm{PC}$ 系には式(17)を, $\mathrm{PX}$ と $\mathrm{PX}(\mathrm{SC})$ 系には 式(18)，PM 系には式(19)を適用して相対損失弾性率 $\left(E_{c}^{\prime \prime} /\right.$ $\left.E_{0}^{\prime \prime}\right)$ からそれぞれ $\Delta R$ を計算した. Table 4 に結果を一
括した。なお，PC系は $E_{0}^{\prime \prime}$ と $E_{c}^{\prime \prime}$ がほとんど差がないた め意味のある值が得られなかった，PC系の場合，動的 粘弾性の結果からも相互作用が極めて弱いことが推測さ れる，その他の系の $\Delta R$ はやはり非常に大きく，また充 てん量によって大きく異なる．ただし相互作用の強さの 傾向は Pliskin 法の結果と一致し, $\mathrm{PM}>\mathrm{PX}(\mathrm{SC})>\mathrm{PX}$ の順位は変らない. 以上のことから Ziegel 法では相互 作用の強弱の比較は可能であるが，バウンドポリマーの 厚みを定量するには不適当であると考える.

Table 5 に以前 Droste 法で求めた PX 及び PX(SC) 系 の $\Delta R$ を今回得られた結果と比較して示しておく. Droste 法と Pliskin 法とが大変よく一致している。 なお Droste 法は界面近傍にポリマーの不動層が形成されて, それに伴って Tgが上昇するということが理論の根底に なっている.したがって Tgの上昇しない複合系は相互 作用が弱いことになるが，必らずしも相互作用の強弱と $\mathrm{Tg}$ の上昇が関連するかどうか疑問である. Tg の上昇の 有無はマトリックスポリマーとフィラーの組合わせで様 ざまである6). 本研究の場合でも PM 系は PX と異なり, $E^{\prime \prime}$ の $\alpha$ ピークの温度シフトから見る限り $\mathrm{Tg}$ の上昇は ほとんど見られなかった。したがって PM系のように Droste 法で $\Delta R$ を求めることができないケースも出て くる，それで相互作用を評価する場合，複数の手法から の結果をつき合わせて判断することが必要と思われる.

Table 5 Comparison of $\Delta R(\AA)$ from each method about $\mathrm{PX}$ and $\mathrm{PX}(\mathrm{SC})$ systems

\begin{tabular}{lccc}
\hline \multirow{2}{*}{ system } & \multicolumn{3}{c}{ method } \\
\cline { 2 - 4 } & Droste's & Pliskin's & Ziegel's \\
\hline PX & 71 & 92 & $1100-1300$ \\
PX (SC) & 142 & 147 & $1400-2200$ \\
\hline
\end{tabular}

Table $4 \quad E_{c}^{\prime \prime} / E_{o}^{\prime \prime}$ and $\Delta R(\AA)$ for each materials [( -$)$ : unable to calculate]

\begin{tabular}{|c|c|c|c|c|c|c|c|c|}
\hline \multirow[b]{2}{*}{ PVC/filler } & \multicolumn{2}{|c|}{$\mathrm{PX}$} & \multicolumn{2}{|c|}{$\mathrm{PX}(\mathrm{SC})$} & \multicolumn{2}{|c|}{ PM } & \multicolumn{2}{|c|}{$\mathrm{PC}$} \\
\hline & $E_{c}^{\prime \prime} / E_{o}^{\prime \prime}$ & $\Delta R$ & $E_{c}^{\prime \prime} / E_{o}^{\prime \prime}$ & $\Delta R$ & $E_{c}^{\prime \prime} / E_{o}^{\prime \prime}$ & $\Delta R$ & $E_{c}^{\prime \prime} / E_{o}^{\prime \prime}$ & $\Delta R$ \\
\hline $90 / 10$ & 0.96 & - & 1.17 & 3200 & 1.47 & 37000 & 0.91 & - \\
\hline $80 / 20$ & 1.11 & - & 1.41 & 2800 & 1.75 & 22500 & 0.93 & - \\
\hline $70 / 30$ & 1.34 & 1100 & 1.50 & 1800 & 1.80 & 12600 & 1.11 & - \\
\hline $60 / 40$ & 1.61 & 1100 & 2.16 & 2200 & 1.77 & 6500 & 1.14 & - \\
\hline $50 / 50$ & 2.24 & 1300 & 2.32 & 1400 & 2.08 & 4800 & 1.27 & - \\
\hline
\end{tabular}

Constant for calculation: $\mathrm{R}=1$ for $\mathrm{PC} ; \mathrm{R}=0.5, \mathrm{~L}=20$ for $\mathrm{PX}$ and $\mathrm{PX}(\mathrm{SC}) ; \mathrm{D}=60, \mathrm{X}=2$ for $\mathrm{PM}$. 


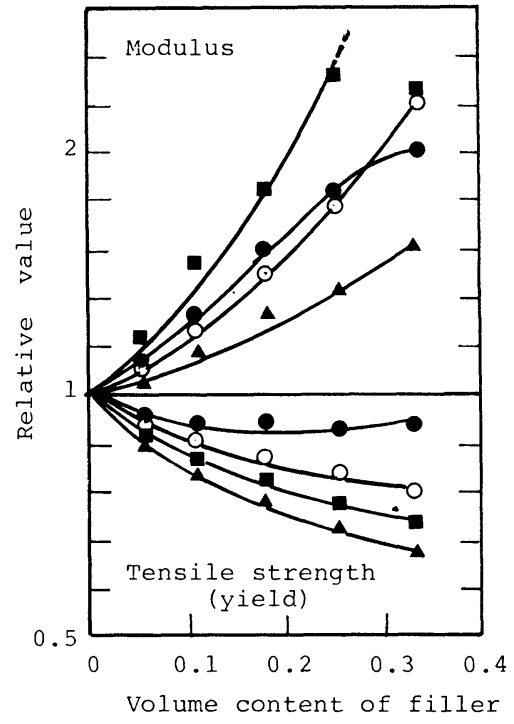

Fig. 3 Relative modulus and tensile strength of filler filled PVC systems. $\bigcirc \mathrm{PX} \bigcirc \mathrm{PX}(\mathrm{SC}) \backsim \mathrm{PM} \Delta \mathrm{PC}$

\section{3 相互作用と力学的性兵の関係}

Fig. 3 に相対弾性率と相対引張強さを示した. 弾性率 を見るとマイカ系が一番高く, 次いでシラン処理ゾノト ライト，未処理ゾノトライトそして炭酸カルシウムの系 となっていて，相互作用の強さの順となっている. した がって相互作用の強弱と弾性率の間にかなり関連性が認 められる. マイカやゾノトライトの系が示した $\Delta R$ の大 きさはゴムとカーボンブラックなどとの系で一般にいわ れているより大きい値を示している. 特にマイカは予想 以上に大きい. マイカやゾノトライトは非常に高い弾性 率補強効果を示すフィラーとして知られているが，形状 効果もさることながら強い相互作用が相当に寄与してい るものと考えられる.Fig. 4 に以前著者らが $3 \mathrm{~mm}$ 厚の 別試料について測定した曲げヤング率を示しておく.

Kerner は粒状の ${ }^{5)}$, Wu は棒状のフィラーのための理論 式7である。これらの理論式は界面での相互作用や空隙 効果などが一切考慮されていない. したがって，ゾノト ライトの場合 Wu曲線より高めに出ていることから形 状効果以外に相互作用がヤング率にかなり影響している ことが, これからも推察できる. 一方, 小変形域の力学 的性質であるヤング率などと違って大変形域の挙動を示 す引張強さになると Fig. 3 でも見られるように様子が

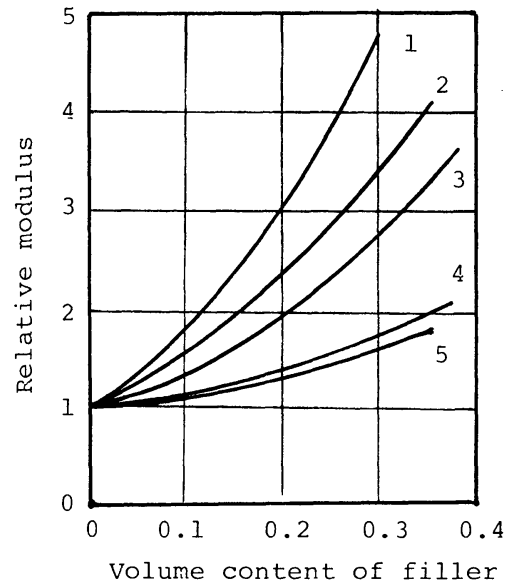

Fig. 4 Dependence of the relative modulus on volume content of filler for (1) PVC-mica, (2) PVC-xonotlite, (3) Wu equation, (4) Kerner equation and (5) PVC-calcium carbonate systems.

異なってくる．すなわち PM 系はそれほど強くない. 大変形域の性質には相互作用が少々強くても陰にかくれ てしまって, 他の要因, 例えば空隚とか傷, 応力集中と いったものに強く支配されるようになるためと考えられ る.ただし，シランカップリング剂処理のように界面に 化学結合が存在すると引張強さが増大することは FRP を始め各種強化複合材料において実際に見られるところ である，PVG-ゾノトライトの系でも同様である．大変 形を伴う力学的挙動はその意味でも複雑で, 相互作用の 強弱とは一義的には関連しないと考えてよい.

\section{引用 文 献}

1) Droste, D. and Diebendetto, A.: J. Appl. Polym. Sci., 13, 2149 (1969).

2) Pliskin, I. and Tokita, N.: J. Appl. Polym. Sci., 16, 473 (1972).

3) Ziegel, K.: J. Colloid Interface Sci., 29, 72 (1969); Ziegel, K., and Romanov, A.: J. Appl. Polym. Sci., 17, 1119 (1973).

4) Souma, I.:J. Appl. Polym. Polym. Sci., 27, 1523 (1982).

5) Kerner, E.: Proc. Phys. Soc. London, B69, 808 (1956).

6）佐藤弘三：“充てん高分子の物性”理工出販（1978） p. 106

7) Wu, J. T.: Int. J. Solids Struct., 2, 1 (1966). 


\section{INTERACTION BETWEEN POLY (VINYL CHLORIDE) AND IN- ORGANIC FILLERS}

\section{SOUMA and M. KISHIBE (Government Industrial Research Institute, Osaka Midorigaoka 1-8-31, Ikeda, Osaka, 563)}

A thickness of bound polymer was determined about PVC-mica, -xonotlite (calcium silicate) and -calcium carbonate composite systems. The determination was carried out using both methods of Pliskin and Ziegel. The determined thickness by Pliskin's method was about $230 \AA$ on mica, $150 \AA$ on silane coupling agent treating xonotlite and $90 \AA$ on non-treating xonotlite. That of calcium carbonate was negligible. While, Ziegel's method gave an unsuitable large value for bound polymer, however, the order in the thickness was same as the case by Pliskin's method. About the reinforcing effect of these fillers on mechanical properties, mica was highest on modulus, subsequently it was in order of silane treating xonotlite, non-treating xonotlite and calcium carbonate. Therefore, it was considered that a strong interaction contributes a large modulus to the composite system.

(Received September, 9, 1985)

\section{昭和61年度正会員会費払込みのお願い \\ 正会員会費 年額7,200円 学生会員会費 年額 3,600 円}

昭和61年度分の会費未納の方は至急お払込み下さい. 御承知のとおり協会誌の発行, 総会の開催, 講 演会, 講習会, 見学会のほか本会の行事は, すべて会員の皆様の会費により運営されるもので, 本会発 展のため深い御理解をお願い申しあげます。

\section{会費切れに伴い，会員資格が大幅に制限されます}

本会行事に参加のとき未納会費がありますと参加できないことがあります．また協会誌・行事案内な どがお送りできず, 協会誌の在庫切れ, その他いろいろと御不便をおかけすることになります，ぜひ本 誌とじ込みの振賛用紙を御利用願うか, 現金書留・銀行振込などによりお払込み下さい，なお，その際 は送金内訳，会員名その他必要事項はお忘れなく御記入願います。

○郵便振替の場合の場合 : 本誌とじ込みの振替用紙で最寄りの郵便局より御送金下さい.

○銀行振込の場合 : 次の銀行口座へお振込み願います。住友銀行日比谷支店普通預金口座 No. 152069, 三井銀行日比谷支店普通預金口座 No. 920-128, 協和銀行赤坂支店普通預金口座 No. 502441, 太陽神戸 銀行虎/門支店普通預金口座 No. 1007470, 第一勧業銀行虎/門支店普通預金口座 No. 1228682, 三菱 銀行本店公務部普通預金口座 No. 0002676. なお，振込手数料は御負担願います.

○請時書の発行について：原則として発行いたしませんが，御入用の節はお手数ながらお申出下さい. 〉領収書の発行について : 郵便振替, 銀行振込による御送金の際に発行される振込票が領収書となりま すので，現金書留による送金以外には原則として発行いたしておりません．御入用の節はお手数ながら お申し出下さい(郵便振替では通信欄を御利用いただくと御便利です). 